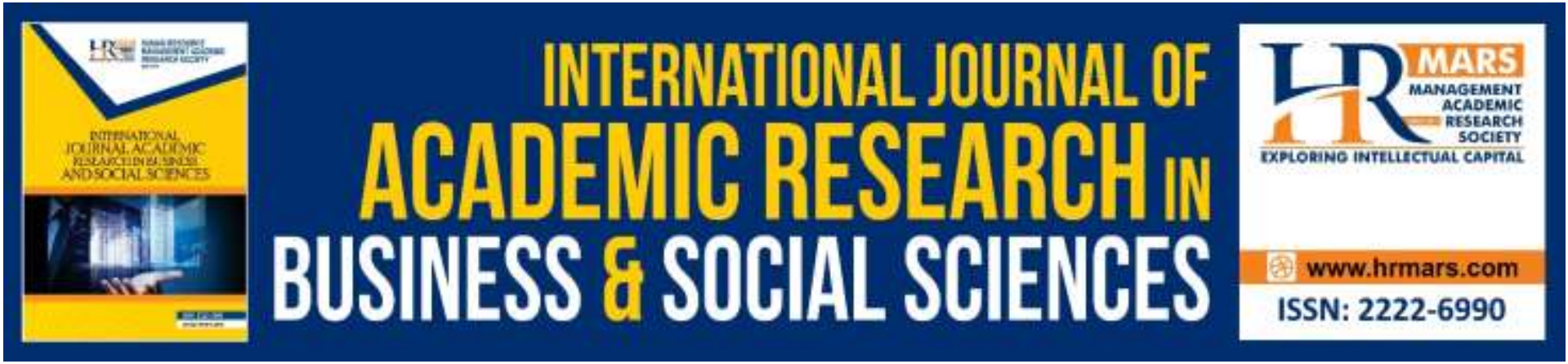

\title{
History of Astrology and Astronomy in Islamic Medicine
}

\section{Norzakiah binti Saparmin}

To Link this Article: http://dx.doi.org/10.6007/IJARBSS/v9-i9/6293

DOI: $10.6007 /$ IJARBSS/v9-i9/6293

Received: 12 July 2019, Revised: 07 August 2019, Accepted: 30 August 2019

Published Online: 20 September 2019

In-Text Citation: (Saparmin, 2019)

To Cite this Article: Saparmin, N. binti. (2019). History of Astrology and Astronomy in Islamic Medicine. International Journal of Academic Research in Business and Social Sciences, 9(9), 282-296.

Copyright: (C) 2019 The Author(s)

Published by Human Resource Management Academic Research Society (www.hrmars.com)

This article is published under the Creative Commons Attribution (CC BY 4.0) license. Anyone may reproduce, distribute, translate and create derivative works of this article (for both commercial and non-commercial purposes), subject to full attribution to the original publication and authors. The full terms of this license may be seen at: http://creativecommons.org/licences/by/4.0/legalcode

Vol. 9, No. 9, 2019, Pg. 282 - 296

http://hrmars.com/index.php/pages/detail/IJARBSS

JOURNAL HOMEPAGE

Full Terms \& Conditions of access and use can be found at http://hrmars.com/index.php/pages/detail/publication-ethics 


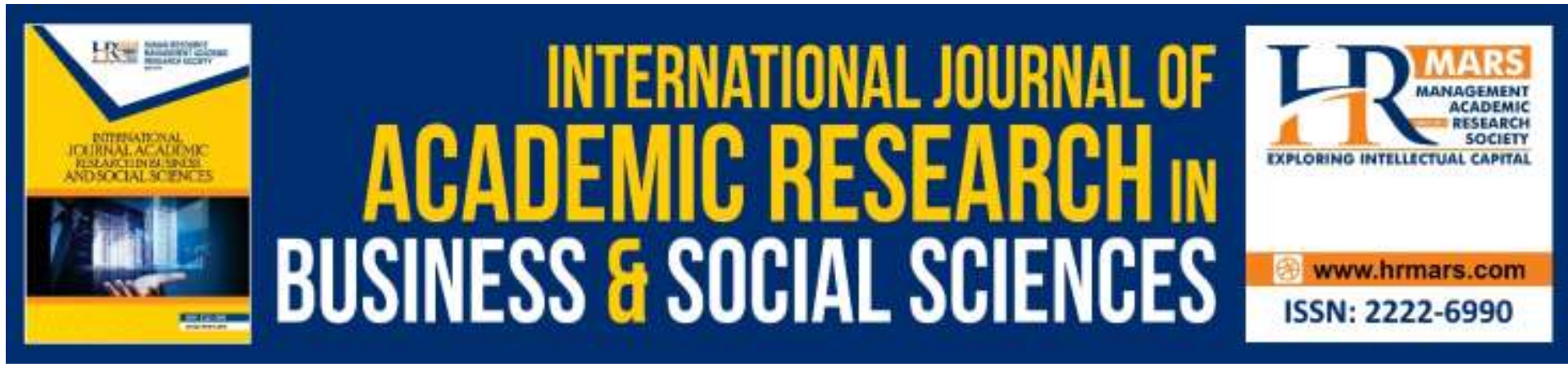

\title{
History of Astrology and Astronomy in Islamic Medicine
}

\author{
Norzakiah binti Saparmin \\ Department of Computational and Theoretical Science, \\ Kulliyyah of Science, International Islamic University of \\ Malaysia (IIUM), Kuantan, Pahang, Malaysia
}

\begin{abstract}
Living in the desert with an open space and a clear night sky, the Arabs had always depended on the stars to guide them on their travels, to determine the progression of time and the changes of seasons and weather, which were important for their agricultural and trading needs. These dependencies on the stars, however, did not stop at these physical phenomena only, but extended also into divination such as astrology and geomancy, which continued even after the coming of Islām. Although Islām clearly rejects astrology, this paper attempts to show that astrology-which somehow includes also some knowledge of astronomy, since during the medieval period, a practicing astrologer is also a skillful astronomer-continued to be practiced widely and openly by the Muslims, in the market place, on ships, at deathbeds and even in the caliph's court. This paper, however, will only touch one area where astrology seems to have some good reputation, which is in the field of medicine. Although astrology had its own opponents, especially among the religious scholars, it was welcomed in the caliph's court and was practiced openly by some of the physicians. We will delineate how and to what extent astrology and astronomy contributed into their field of medicine. The methodology of the paper is a literature review in the history of astrology and astronomy in the Islamic civilization.
\end{abstract}

Keywords: Astrology, History of Astronomy, Islamic Medicine, Islamic Civilization

\section{Introduction}

Living in the desert with an open space and a clear night sky, the Arabs had always depended on the stars to guide (ihtid $\bar{a}^{\prime}$ ) them on their travels, to determine the progression of time and the changes of seasons and weather, which were important for their agricultural and trading needs. These dependencies on the stars, however, did not stop at these physical phenomena only, but extended also into divination such as astrology and geomancy, which continued even after the coming of Islām. Although Islām clearly rejects astrology, this paper attempts to show that astrology-which somehow includes also some knowledge of astronomy, since during the medieval period, a practicing astrologer is also a skillful astronomer-continued to be practiced widely and openly by the Muslims, in the market place, on ships, at deathbeds and even in the caliph's court. This paper, however, will only 
touch one area where astrology seems to have some good reputation, that is, in the field of medicine. First, we will give a general information on how astrology began to take roots in ancient Babylon and Mesopotamia, which later it was transferred to Egypt, Greek, Syria, Persia and to some extent to India, and how these foreign sources later contributed to the revival of astrology in the Muslim lands during the active translation period of late $8^{\text {th }}$ to $9^{\text {th }}$ century of the 'Abbāsid dynasty.

Sources of Astrology from the Babylonian and Mesopotamian Civilizations: The earliest recorded evidence of astrological divination was found written in cuneiform script in Mesopotamia. The script was invented by the Sumerians, who lived in the Mesopotamian area from around the $4^{\text {th }}$ millennium BCE. There were evidences that they had already given names to some of the prominent stars in the sky and considered them to be a god-like nature, complete with sacrificial rituals.

Sacrificial rituals can also be seen from recorded evidence from the Old Babylonian text dated around 1800 BCE known as "Prayers to the Gods of the Night": "Many the great Gods of the night, Shining Fire-star, heroic Irra, Bow-star, Yoke-star, Sitaddaru, Mushussustar, Wagon, Goat-star, Goat Fish-star, Serpent-star, stand by and part a propitious sign on the entails of the lamb I am blessing now" (Barton, 1994). The list of the star names above went through some changes before it was set in its final form, inherited by the Arabs astrologers and astronomers, and then later transferred to the West, and became the familiar names of the constellations that we know them today. In a Babylonian text known as Mul Apin (the Plough Star), which was written about 1000 BCE and completed about 700 BCE, there were already existed seventeen names of the modern constellations being put down by the Babylonians such as the constellation of Taurus the Bull, Cancer the Crab, Leo the Lion, Libra the Balance, Scorpio the Scorpion, Capricorn the Goat-fish, the Tails (Pisces), the BarleyStalk (Virgo) and Gemini the Great Twins.

Furthermore, Babylonian astrology was also one of the foreign sources that did contribute their skill and craft of astrology to Muslim astrologers and astronomers. Some of the Babylonian astrologers and astronomers mentioned by Ibn Nadim (d. $10^{\text {th }} \mathrm{CE}$ ) in his Fihrīst are Tinkalus, who was one of the seven learned men whom were in charge of the seven shrines in Babylon, which were built on the honor of the seven planets; Tinqarus, who was also one of the seven learned men and he was in charge of the shrine of Mars, and written a treatise known as Nativities; Qaytawar, who authored a book entitled Starcraft; and Teukros or Tankalusha (fl. ca. $1 \mathrm{CE}$ ), who has his book translated into Arabic as Kitab al-Mawālīd 'alā I-Wudjūh wa 'I-Hudūd (Dodge, 1970). Their skills and writings must have been quite well known and circulated among the Muslims astrologers in the period between $8^{\text {th }}$ to $10^{\text {th }}$ centuries CE.

Babylonian and Mesopotamian astrology was later transmitted to Egypt, in which it received further modifications in terms of its contribution to medicine. Here, in ancient Egypt, astrology is known as Hermetic astrology, derived from the name of the Egyptian God, Hermes. The astrology included a study on the correspondences between the heavenly phenomena and the human body. This is known as melothesy, in which, for example, certain parts of the body is related to one of the constellations, such as the head is related to Aries, neck and shoulders are related to Taurus, and breast is related to Cancer (Budge, 1976). All these are part and parcel of astrological medicine, or scientifically known as iatromathematika. It is a complicated discipline developed by these ancient people to predict, 
when and how to treat, and where to find the right kind of treatment of various kinds of illnesses and diseases. For example, for each of the seven known heavenly objects at that time-the sun, the moon and the five planets, Mercury, Venus, Mars, Jupiter and Saturn-there is a specific correspondence of their movement and positions to earthly objects such as metals, stones, plants and animals, the commonly used drugs and therapeutic treatments at that time, or in medical terminology, these various kinds of natural products are known as simples of medicine or materia medica (Culianu, 1987). This so called astro-botany, as we shall see later became an important part of astrological medicine practiced by many of the Islamic physicians.

Sources of Astrology from the Greek Civilization: The skill and craft of ancient astrology was then transmitted to the Greeks, and here it received further sophistication and systematization by many of the famous Greek astronomers and astrologers such as Ptolemy, Dorotheus of Sidon, Hermes and Vettius Valens. Many of their astrological and astronomical teachings are still retain up until the modern times such as the names and the forms of the twelve zodiacal constellations, Aries, Pisces, Aquarius, Capricorn, Sagittarius, Scorpion, Libra, Virgo, Leo, Cancer, Gemini and Taurus, and even the term zodiac itself came from the Greek word zodiakos (from zoidion, "carved figure") established somewhere around $5^{\text {th }}$ century BCE. Their writings and teachings also exerted great influence on Islāmic astronomy and astrology. There are no other ancient sources that have so much impact on the development of Islāmic astronomy and astrology other than the two most important books of Ptolemy, the Almagest and Tetrabiblos. While Almagest is exclusively for the use of astronomers, Tetrabiblos or Kitāb al-Arba'a was translated more than once and was commented upon by many of the great Muslim astrologers such as Ibn al-Farrukhan, Ibn al-Salt, al-Nayrizi and al-Battani (d. 992 CE) (Saliba, 1982). Ibn Riḍwān, the famous $11^{\text {th }}$ century Egyptian physician-astrologer, wrote an extensive commentary on Tetrabiblos, which was later translated into Latin. Other than Ptolemy's Tetrabiblos, the five books of Dorotheus of Sidon, Hermes's "What is Hidden in the Secret of the Stars," and Vettius Valen's "An Introduction to the Science of Astrology," which was written somewhere between 152 and $188 \mathrm{CE}$, also exerted much influence on the development of astrology in the Islāmic civilization during $8^{\text {th }}$ to $10^{\text {th }}$ century CE. All of them were mentioned by Ibn Nadīm in his Fihrīst.

In Tetrabiblos, Ptolemy had noticed the direct physical influence of the heavenly objects onto earthly beings as he said (as quoted by Ibn Khaldūn in his Muqaddimah): "........the activity of the sun and the moon and their influence upon elemental things are so obvious that no one can deny them. For instance, the sun influences the changes and tempers of the seasons, the ripening of fruits and grains, and so on. The moon influences humidity, the water, and the (process) of ripening (putrefaction) in putrescent substances and cucumbers, and so on" (Rosenthal, 1967). These direct physical influences, and in addition of attributing the heavenly spheres as something immutable, does not change places and does not vary in substance, size and color, inevitably lead the Greeks to believe into astrological divination.

Concerning health, even the prominent Greek physicians like Galen and Hippocrates, who set the direction of Islāmic medicine, also gave some considerations to astronomy and astrology. In his book On Airs, Waters and Places, Hippocrates said: "That astronomy contributes not a little, but a very great deal indeed to medicine. For with the seasons, the digestive organs of men undergo change. For knowing the changes of the seasons, the risings 
and settings of the stars, how each of them takes place, he will be able to know beforehand what sort of a year is going to ensue" (Hutchins, 1978). Hippocrates also would look up into the sky to help him to make some medicinal predictions, as he said, "And if at the rising of the Dogstar (Sirius) rain and wintery storms supervene, and if the etesian winds blow, there is reason to hope that these diseases will cease, and that the autumn will be healthy" (Hutchins, 1978). In his book of the Epidemics, Hippocrates discussed the changes of weather and seasons in a place called Thasus, according to the changes of the heavenly sky, "In Thasus, about the autumn equinox, and under the Pleiades (a group of star cluster near the constellation of Taurus), the rains were abundant, constant and soft, with southerly winds; the winter southerly, the northerly winds faint, droughts; on the whole, the winter having the character of spring" (Hutchins, 1978).

Galen also had a good opinion on astrology as he said in his book, Prognostics from the (time of the patient's) taking to bed: "Astrology is the foreseeing part of their (i.e. the physician's) art, and if not all, but at least most of them have accepted this part of astrology as part of medicine ........ Hippocrates said that (any physician's) mind strays into darkness, which has not used physiognomy. But the physiognomic part of astrology is its major part" (Barton, 1994). Galen and Hippocrates furthermore, in prognosticating the illness of their patients, would observe the "critical days," the days on which the illness would become better or worse, of their patients, in accordance to the changes of the heavenly objects. For example, Galen in his third book of On Critical Days mentioned that the critical days of the moon are seven days after the new moon, after nine days, after fourteen days and etc. Galen also believed in astro-botany, in which he would depend on the position of the heavenly objects in order to find out the proper place and time to obtain various kinds of therapeutic herbs and drugs, including medicinal stones. Also he believed that therapeutic plants that are connected to the moon can induce menstruation, since he noticed that the periodicities of menstruation seem to be following the phases of the moon. Hippocrates also believed that the full moon can aid in giving birth (Barton, 1994).

Sources of Astrology from the Syrian, Persian and Indian Sources: The skill and art of the Greeks in astrology and medicine was then transmitted to the Syrians, who translated and kept the books and manuscripts in their Syriac language before they were brought to the Muslim lands. For example, in the Syriac Book of Medicine, there is mentioned the astrology of melothesy, the art which we have mentioned before relates the different body parts to the constellations. They also considered that eclipses and comets, or better known to the ancients as tailed-stars, are bad omens. For example, in the book it is said that if the eclipse took place in Libra, or in Aquarius, or in Gemini, it forecasted that pestilence will occur among men throughout the world. Also a comet and a shooting star indicate a sign of famine and pestilence (Budge, 1976).

Furthermore, the Syrian divided the constellations into four groups, in which each of the group is said to rule over the living beings on earth, for example, Gemini, Libra and Aquarius are said to be masters of men and birds; Taurus, Virgo and Capricorn are said to be masters of the trees and grass (or herbs); Aries, Leo and Sagittarius are masters of the fourlegged creatures; and Cancer, Scorpion and Pisces are masters of aquatic animals. They also have astrological predictions to forecast if the sick person will die or recover. For example, if a man fall sick when the moon is in Virgo or in Libra, he will die. Furthermore, certain symptoms of illness are connected to different constellations, for example if a man is sick 
while the moon is in Virgo, his bowels and shoulders will cause him pain, he will stand in a dejected attitude, and winds will strike within him, but if the moon is in Taurus, his palate will cause him pain. Planets also carried certain symptoms, for example, Kronos (Saturn) would produce headache, gout, cold (chill), coughs, shortness of breath and dropsy, while Zeus (Jupiter) would produce ulceration of the throat, stoppages of the bowels, scrofula, inflammation of the throat and gums, and pain in the liver (Budge, 1976).

Other than the works of the Syrians, Indian astrology also played a considerable part in propagating astrology to the Muslims. Ibn Nādim in his Fihrist listed more than a dozen names of Indian astrologers and astronomers who had works on astrology and medicine transmitted to the Muslims, such as Kankah on "Secrets of Nativities and Conjunction," Judar on "Nativities," and Sanjahil on "Secrets of the Questions" (Dodge, 1970). Al-Bīrūnī also was said to translate a nativity book of a $6^{\text {th }}$ century Indian philosopher, Varahamishira, entitled in Arabic as Kitāb al-Mawālīd al-Șaghìr. Another Indian astrologer, Kanaka, who served at the court of Hārūn al-Rashīd also wrote on nativity, known as Kitāb al-Mawālīd. The Indian astronomy also influenced the Arabs anw $\bar{a}^{\prime}$ books, books on a list of stars' names, stars which are mostly situated near the path of the sun and the moon, developed by various Arab tribes during the pre-Islāmic times, for measuring the progression of time and forecasting weather. In these books, the Arabs included the 28 lunar mansions, the 28 portions of the sky traced out by the moon in 28 days or 1 month according to the lunar calendar and which was developed by the Indian, into their anwa' system (Kunitzsch, 1983).

Among the most influential of the foreign sources to Islāmic astrology, with the exception of the Greeks, were the Persians. It was at the time of the 'Abbāsid caliphate when many Persian works were brought to Baghdad, including their craft in astrology. Instead of banishing it as an occult science, astrology gain a prominent reputation among the ruling class: "In order to imitate the Sasanid Kings, the 'Abbāsid caliphs, who in most cases had Persian tutors (in particular al-Rashīd and al-Ma'mun) adopted customs (including astrology) which were at odds with the Arab spirit and Islām" (Fahd, 1983). The most prominent among them who served at the 'Abbāsid's court was Abū Sahl al-Faḍl Ibn Nawbakht. He was consulted by al-Mansūr, together with Māshā'allāh (d. 200/825), the famous Jewish astrologer, to determine the auspicious time for the caliph to start building the foundation of his new 'Abbāsid capital at Baghdād. Ibn Nawbakht also served at Bayt al-Hikmah of Hārūn al-Rashīd, and has a well-known book on astrology known as Liber Alfadhol in Latin, a lot book contains 144 major stars acting as "judges," answering questions, and guiding astrologers to acquire their needed solutions.

Other than Ibn Nawbakht, another famous Persian astrologer also known to the Arabs was Zarathustra, who has a nativity book also entitled as Kitāb al-Mawālīd (Fahd, 1983).

The Persians also acted as intermediary of some of the Greek astrological works. There were some books written by Greek authors which were kept in Pahlavi and then translated later into Arabic, such as Kitāb al-Mawālīd of Vettius Valens and Hermes's Thirty Bright Stars. Furthermore, the Arabs also adopted from Pahlavi certain names for the celestial objects, such as the term for shooting stars or meteors, shihab (shuhub) or nayzak (nayazik), and one of the terms used for fixed stars in Arabic, al-kawākib al-biyābāniya, is from the Pahlavi a-wiyābān-īg, which however has been taken from the Greeks (Kunitzsch, 1983).

All these foreign sources above contribute immensely to the development of astrology in the Muslim lands. We will see now how astrology developed within the expanding Islāmic empire and civilization, and the role it plays in Islāmic medicine. 
History of Astrology and Astronomy in Islamic Medicine: Ibn Khaldūn in his Muqaddimah defined the science of astrology as "a discipline of drawing from the cyclical and permanent movements of the celestial bodies indications which have a bearing in this world of change and corruption" (Fahd, 1983). He divided the field into three parts, mathematica (hisābiyyāt) and physica (țabīiyyāt) which comprised the astronomical part of astrology, and fantasmagorica (wahmiyyāt), the divination part of astrology. Abū Ma'shar al-Falakī, one of the greatest astrologers of the Arabs and Latin Middle Ages (d. 272/886), defined astrology as: "the knowledge of the effects of the power of the stars, at a given time, as well as the future time" (Saliba, 1982). Another famous astrologer in Islām, al-Bīrūnī, in his important book on astrology entitled Kitāb al-Tafhìm li awāil Șanā'ah al-Tanjim, defined astrology as the subject by which "we understand the nature of the universe, the causes and reasons of the nature of the sky and earth, and what is in between these two" (Namus, 1979). There are many names given by the Muslim scholars to this discipline we know as astrology, such as ilm' ahkām al-nujūm (science of the decree of the stars) or ilm' al-aḥkām, usually to distinguish it with astronomy, which is called 'ilm al-falak or 'ilm al-hay'ah. Both, however, were commonly known as 'ilm al-nujūm or the science of the stars, but was distinguished completely from each other somewhat later in the $13^{\text {th }}$ century after a series of attack from the well-known religious scholars such as al-Jāḥiz (d. 869 CE), Ibn Hazm (d. 1064 CE), al-Ghazzālī (d. 1111 CE), Ibn Qayyim al-Jawzīyyah (d. 1349 CE) and even Ibn Khaldūn himself.

But in spite of these setbacks, astrology did not completely die, but was commonly practiced by the masses and the caliphs themselves. Ibn Nādīm in his Fihrist put down more than 25 names of Islāmic astrologers and astronomers who had written and contributed something on astrology between $8^{\text {th }}$ to $10^{\text {th }}$ centuries CE. Their skills were quite demanding and they were often being asked to serve at the caliph's court, even for day to day tasks. AlJāhiz, in his Bāb al-'Irāfa, wrote that the $9^{\text {th }}$ century 'Abbāsid caliphs would ask astrologers to examine the days of the week, judge them and appraise them in the interests of the King. The caliphs even acknowledged the astrologers' skill in treating disease and illness, as it happened once when Sultan al-Malik an-Nāșir Muḥammad Ibn Qalāwūn, a 15 $5^{\text {th }}$ century Mamluk King, became ill with diarrhea, not only the physicians but also the astrologers and geomancers were asked for their opinion (Ullmann, 1978). And as we shall see further, there were many physicians in Islām such as 'Isā al-Dimashqī, 'Alī ibn Sahl aț-Ṭabarī, Ibn Zuhr, Ibn Butlan and alKindī whom not only served their caliphs as physicians, but also became their courtastrologers.

Astrology and astronomy in fact has become part and parcel of Islāmic medicine. A Muslim physician was noted to have said, "In addition to the purely medical knowledge it was held desirable, though not essential, that the medical student should have also studied geometry in order that he might know the shapes of the wounds ........, astronomy or astrology so that he might know the lucky and unlucky quarters of the moon, and music......" (Elgood, 1951).

The role which astrology plays in Islāmic medicine are mostly in the area of judicial astrology, that is in hemerology (ikhtiyārāt) and genethlialogy (mawālid). In hemerology, the method of astrology in deciding when is the auspicious ( $s a^{\prime} d$ ) and the inauspicious (nahs) time for performing certain tasks, an astrologer-physician for example, would advise, "If you wish to start an alchemical work or anything requiring fire, or any kind of work you may have to repeat, start that when the moon is in a bicorporeal sign ........" (Saliba, 1982). Or for certain crucial and dangerous medical treatment like cupping, he would say, "the best time for 
cupping is in the middle of the month, when the humours are in a state of agitation, and during the time when the moonlight is increasing" (Elgood, 1951). In one of the stories in Arabian Nights, it is also mentioned that when cupping was about to perform, the signs of the sky were first observed: "When your father said to me, "draw my blood," I fetched the astrolabe and found that the constellation of the hour was unfavourable" (Ullmann, 1978). A physician-astrologer would also combine their doctrine in melothesy and hemerology in their treatment, for example, he would say, "the proper time for performing venesection was before midday, after the digestion of the morning meal and after the bowels had moved. Each organ of the body was believed to be connected with one of the signs of the zodiac. To let blood from a member during the sign of the moon governing that part was a perilous procedure" (Elgood, 1951). Some of the literature that have been written on hemerology are al-Kindī's Ikhtiyārāt al-Ayyām, and Fakhr al-Dīn al-Rāzī's al-lkhtiyārāt al-'Alä'iyya.

The other branch of judicial astrology, genethlialogy, received wider attention by the Islāmic astrologers. It was first introduced in the 'Abbāsid court by the Persians, who brought along with them many works on mawälïd literature written in Pahlavi, and in Greek, which were then translated into Arabic, such as Kitāb Mawālid al-Rijāl and Kitāb al-Mawälīd al-Nisā' 'alā ra'y Hirmis wa Bațlamyūs (Hermes and Ptolemy), and many others which we have mentioned above as part of the foreign contribution into Arabic astrology. Māshāallāh, the $9^{\text {th }}$ century Jewish 'Abbāsid astrologer, in his Kitāb al-Mawālīd, divided genethlialogy into five parts:

1. Knowledge of the beginning of the formation of the foetus and the observation of its stages before birth.

2. Knowledge of the position of the heliacal star at the moment of birth.

3. Education.

4. Knowledge of the age by means of al-hilaj, its positions and those of the stars which are responsible for it.

5. The form of the body, its external appearance and temperament (Fahd, 1983).

There were also Muslim astrologers who were active in translating, commenting and writing mawālīd literature such as Abū Ma'shar, with his Kitāb Aḥām Taḥwīl Sinī l-Mawālīd and Kitāb al-Mawālīd al-Kabìr and al-Șaghīr; 'Umar b. al-Farrukhān, who has a compilation of the nativity writings of Hermes, Dorotheus and Ptolemy; and Abū Bakr al-Hasan b. al-Khașīb, or known in Latin as Abubather, who has his book Liber de nativitatibus, preserved only in Latin.

An example of a genethliac prediction would be something like this: "if the native is born with the moon within the limits of Mercury, and Mercury is holding it from humid places, the native will have the inclination for painting, engraving, embroidering and the like" (Saliba, 1982). A prediction can also be very general, describing each stage of the human life in terms of its physical and spiritual development, as the prediction made by the Spanish Muslim physician-astrologer, 'Arīb ibn Sa'îd (d.c. 980 CE) who said "that the first four years of a child's life are determined by the cold and wet moon whose sphere is nearest to our earth. For this reason, the small child is weak, fragile and stupid, and can eat only a little. These four years correspond to the four elements. The following ten years form the second period of life under the dominance of Mercury, whose sphere lies over that of the moon. During this period, the child shows signs of attention, reflection and the power of discrimination, so that he can take the first steps in the sciences. Childhood ends at the age of fourteen. Venus, the next higher planet, rules over the following eight years into which fall puberty and the desire for sexual 
intercourse, and in which the young person has to learn self-control. Now follow, as the fourth period of life, nineteen years under the dominance of the sun, a period of time which lasts from the age of twenty-two to forty-one. Here ambition, desire for fame and a serious attitude to life made themselves felt. It is the middle of life, just as the sun occupies a middle place between the subsolar and transsolar planets. In the fifth period of life, this lasts fifteen years until the completion of the fifty-sixth year, Mars reigns. The individual strives after earthly goods, and worries, and works. The following twelve years, that is, the period from the fifty-sixth to the sixty-eighth year of life belong to Jupiter. Now age begins to make itself felt, the individual stands back from his earthly striving and thinks about ethical values and life after death. The seventh period of life, lasting thirty years until the completion of the ninety-eighth year of life, again stands under the dominance of Saturn, which revolves in the highest sphere. The individual loses his strength, his freshness, his hope and his desires, he becomes ill and decrepit, and his body becomes cold. If he survives this age, he again comes under the moon's influence and is again childish like a child" (Ullmann, 1978).

One of the earliest physicians in Islām to write on astrology is Abū'l-Ḥasan 'Isā ibn Hakam al-Dimashqi (d. $840 \mathrm{CE}$ ), the third generation of physician of the Dimashqi family. In his Hārūniyah Epistle, which was the first masterpiece of medical treatise in Islām, dedicated to his patron, Caliph Hārūn al-Rashīd, he wrote about the connection between the seven number of planets with the seven days of the week, and how the perfection and the harmony of the universe reflects the harmonious rhythm and melodies of music (Hamarneh, 1994). In a sense, there is a subtle connection between man, the microcosm, and the universe, the macrocosm. Both reflect each other, and the harmonious relationship between man and the universe should be kept in balance.

Another famous astrologer who also lived in $9^{\text {th }}$ century is the physician-philosopher Ya'qūb ibn Is'hāq al-Kindī (d. $871 \mathrm{CE}$ ). His attitude toward astrology is quite unique. As a philosopher, who lived during the $9^{\text {th }}$ century translation period, al-Kindi studied and commented upon many works of the Greek peripatetic philosophy. Instead of disbanding astrology as a superstitious discipline, his philosophy on the other hand strengthened his belief in astrology. Al-Kindī adopted the Aristotelian cosmology, in which the earth is regarded as the center of the universe, surrounded with four terrestrial spheres of earth, water, air and fire, and eight celestial spheres, with a sphere each for the moon, the sun, the five planets and the fixed stars. The celestial spheres are immutable, unchangeable, and untouchable by the process of generation and corruption which are inevitable for sublunary beings. They were also made from a purer and finer element, which is neither light nor heavy, nor is it moist or dry, known as ether. Furthermore, in his treatise On the Proximate Efficient Cause, al-Kindi believed that the celestial spheres and bodies acted as the intermediary cause, or the proximate efficient cause, between God, the distant cause, and the final recipient of that cause, which is the life on earth. Thus, as the "proximate efficient cause," they were endowed with life, reason and power of discrimination, and even seeing and hearing, since if they are the one who acted as the intermediary cause for the life on earth, how could they be anymore less than the latter? (Atiyeh, 1966)

For al-Kindī, the strongest proximate efficient cause is the sun, while the moon is regarded as a great helper ('aziim al-'awn) to the sun in effecting the life on earth: "the moon is made responsible for the formation of clouds and rain and also for bringing about the most convenient temperature for each of the four seasons. It is by the proper alternation of warm and cold temperature that things integrate and disintegrate" (Atiyeh, 1966). The planets and 
the fixed stars on the other hand, exerted their influence depending upon their temperament, the degree of their magnitude and their distance from earth.

Furthermore, al-Kindi believed that apart from influencing the law of generation and corruption on earth, the heavenly spheres also affected the personal realm of human lives and relationship. Each stage of the human life is related to the four elements, the twelve constellations, the four temperaments, the four humors, the four seasons, and the four terrestrial directions, as follows:

1. Gemini, Libra and Aquarius - childhood - air - moist and hot - blood - spring - east.

2. Aries, Leo and Sagittarius - youth - fire - hot and dry - yellow bile - summer - south.

3. Taurus, Virgo and Capricorn - mature age - earth - cold and dry - black bile - autumn west.

4. Cancer, Scorpio and Pisces - old age - water - cold and moist - phlegm - winter - north (Browne, 1983).

The basic scheme above, which clearly showed the Babylonian, Greek and Persian influences, are much depended by al-Kindī and many other physician-astrologers in Islām who believed in the interconnectedness of everything in the universe. As a physician, they used the scheme above for their daily medical practice in terms of treatment and diagnosis.

Al-Kindī also was a court-astrologer to many of the 'Abbāsid caliphs. During the caliphate of al-Rashīd and al-Ma'mūn, he wrote a book on the effects of conjunction of the heavenly bodies to the rise and fall of the Islāmic empire. He predicted that the 'Abbāsid dynasty would fall and Baghdād would be destroyed sometime in the middle of $7^{\text {th }} / 13^{\text {th }}$ century, which in fact did happen four centuries later, with the fall of Baghdād in the hands of the Mongols. However, his prediction that Islām would last only for 693 years did not come to materialize as his astrological calculation had indicated it to him. During the reign of Caliph al-Mu'tașim, al-Kindī is said to have observed a black spot (mukta sawdä') near the center of the sun for about 91 days. He concluded that the spot may have been caused by the passage of Venus in front of the sun, and considered it to be a bad omen. In fact, a few days later, coincidentally, Caliph al-Mu'tașim died (Kunitzsch, 1983).

Al-Kindī indeed was a well-known astrologer of his time. He wrote many books on astrology, including Risāla fï Illat al-Baḥārīn li-l-Amrāḍ, and De Signis Astronomiae Applicatis ad Medicinam, which is preserved only in Latin. He also taught the subject to many students, including the famous astrologer Abū Ma'shar (Hamarneh, 1994).

Another distinguished physician and also a distinguished astrologer and astronomer during this period was 'Alī ibn Sahl Rabbān aț-Ṭabarī (d. $858 \mathrm{CE}$ ). He composed the first medical encyclopedia in Islām, widely known in Islām and in Latin Middle Ages, as Firdaus alHikmah, or Paradise of Wisdom. The encyclopedia is a compilation of various foreign sources in medicine, including Greeks, Pahlavi, Syriac and Sanskrit. He devoted one section out of seven sections of the book to the science of astronomy and astrology. In the introduction, atTabari wrote that "indeed I have seen that the scholars of India, Rome and Babylon agreed that the heavenly objects disposed (or administered) the earthly objects in one matter to the next" (Siddiqi, 1928). Mentioning Hippocrates, aț-Tabarī wrote that the science of astronomy or astrology is not a small part of medicine, and that the rising of the stars and its setting is a cause that changes the time, and the changes of the time would cause the changes of bodies. Then, quoting Galen from Galen's commentary of Hippocrates's book of "Water, Air and Places," aț-Tabari wrote that for every living thing of the animals on earth there is a definite period of life in its nature (that corresponds to) the period of the movement of the heavenly 
bodies, for example, Galen said that there are animals (or insects) that never lives longer than a day.

Moreover, it is clear from his Paradise of Wisdom that aț-Ṭabari also adopted Aristotelian cosmology when he said that God had made the heaven to be spherical because sphere is the noble and the highest of all forms, it preserves all the other forms, and have the lightest movement compare to the other forms. He also said further that the heavenly spheres were created from the purest and the best part of nature, and not from the four elements, which would have to go through the process of generation and corruption. Furthermore, every beings living below the heavenly spheres seek to achieve perfection and completion as possessed only by these heavenly spheres. At-Tabarī then gave a description of the structure of the universe. He said that the whole universe revolves on the center of the earth like a point in the middle of a circle. First there are seven spheres, with the closest sphere from the earth is the sphere of the moon, and above it is the sphere of Mercury, and above that is the sphere of Venus, then the sphere of the sun, which is the middle sphere of all the seven spheres. And above this sphere is the sphere of Mars and above Mars is the sphere of Jupiter, and above it is the sphere of Saturn. And for each of these seven spheres, there is one star (or planet) only, but above Saturn is the eighth sphere which consists of the twelve constellations and the rest of fixed stars. And above the eighth sphere is the nineth sphere, which is the greatest and the highest object created by God.

At-Tabari also explained how the "light" of the universe being distributed. First, he said that the sun is more luminous (than the other heavenly objects), since it receives light from the fiery ether, then it disposed this "fire" to the atmosphere then to the earth, until the earth become hot and luminous, including its mountains, its seas and its air. At-Tabari also had noticed that the moon borrowed the surplus of its light from the sun. To prove this, he said that if we look at the new moon, its light increases following the path of the sun, and the light reaches its maximum during the half of the month, when the moon is directly opposite to the sun, rising from the east, while the sun is setting in the West, filling the moon with its light (Siddiqi, 1928).

Another illustrious physician-astrologer whom also we would like to mention here is Abū-I Ḥasan 'Alī ibn Riụwān al-Mișrī (d. 1067 CE). He was born in Giza, Egypt, during the period of the Fatimid Dynasty, and once served the Fatimid's Caliph al-Mustanșir (reigned 1035 1094 CE) as a court physician and astrologer (Hamarneh, 1994). He had always believed that the heavenly stars at the time of his birth had indicated to him that someday he would become a physician. But before he could achieve this dream, Ibn Ridwān had to earn and support for himself, including as a part time astrologer, in order to study medicine:

"When I reached my sixth year I began to learn, and when I was ten years old I moved to the capital and urged on my studies. After having completed fourteen years, I began to study medicine and philosophy. I had no fortune with which I could have paid for my education, so that my education was hampered by obstacles and difficulties. Sometimes I earned my livelihood by practicing astrology, again by medical practice, and yet again by giving lessons. So I continued most earnestly my scientific studies until my thirty-second year" (Gamal \& Dols, 1984).

Ibn Riḍwān, through his full commitment and dedication in studying medicine, eventually became one of the greatest physicians ever lived in Egypt. He wrote many medical treatises, including a treatise entitled On the Prevention of Bodily Ills in Egypt, in which he referred to many astronomical phenomena to help him to explain the changes of weather in Egypt and 
their effects on the Egyptian health and temperament. For example, in the chapter "On the Description of Egypt and its Temperament," he said, "It is clear that the sun is directly over the heads of the people in Aswan twice a year: when it is at the end of Gemini and the beginning of Cancer. At these two times nothing standing in this place at midday casts a shadow at all. Heat, dryness and burning are, consequently, dominant over the temperament of this city because the sun dries up the moisture there. Thus, the inhabitants' color is black, and their hair is kinky on account of the scorching of their land" (Gamal \& Dols, 1984).

Furthermore, in the chapter "On the Seasons of the Year in Egypt," it is shown that Ibn Riḍān depended on the movement of the sun through the zodiac to guide him to determine the changes of season, and the rise and fall of the river Nile: "The summer season arrives ........ when the sun is in Gemini, Cancer, Leo, and some Virgo. The heat and dryness become great at this time; the crops dry and the fruits ripen. Eating them causes many bad substances to collect in the bodies. When the sun enters into Cancer, the Nile begins to increase and to inundate the land ....... Autumn, whose nature is dry, when the sun is at the end of Virgo and in Libra and in Scorpio. The Nile reaches its highest point at the beginning of this season and covers Egypt completely" (Gamal and Dols, 1984). The heavenly signs were also useful in guiding physicians when is the right time to give certain drugs, as Ibn Riḍān said, "the winds increase in spring. At this time, the physicians postpone giving purgative drugs until the season comes to rest, when the sun is in Aries and Taurus" (Gamal \& Dols, 1984).

Other "strange" heavenly bodies like comet, was considered as a bad omen. Commenting on a comet which he saw in the year 446 A.H., Ibn Riḍān said, "As this comet rose in the sign of Gemini, which is the horoscope of Cairo, it caused the outbreak of the epidemic (in Cairo) ....... So the warning of Ptolemy came true: "Woe betides the people of Egypt when one of the comets rises in Gemini at the end of the night!" Conjunction of the malefic planets of Saturn and Mars was also considered as a bad sign: "When Saturn and Mars are in conjunction in the sign of Cancer (the foundations of) the world are shaken" (Schaht and Meyerhoff, 1937).

As a practicing astrologer, Ibn Rị̣wān also wrote many excellent commentaries of Ptolemy's Tetrabiblos, and an astrological treatise entitled as "Discourse pointing out the tricks of those who claim wrongly to possess knowledge of astrological prognosis, and on the nobility of the real representatives (of scientific astrology)" (Schaht and Meyerhoff, 1937).

A contemporary to Ibn Riḍwān was the physician-astrologer Abū'l Ḥasan b. Buțlān (d. 1068 CE) from Baghdad. He quoted many astronomical sayings in his book Taquīm al-Sihhah or in Latin known as Tacuini or Tabula Sanitatis, and performed many pharmaceutical and therapeutic treatments, especially in surgery and in distributing out certain drugs or medication, in accordance to the proper time and place as indicated by the heavenly signs. For him, the heavenly objects were indeed a great helper to help him to diagnose and to treat his patients (Hamarneh, 1995).

Another famous physician-astrologer who was also from Baghdad is Abū-Nașr 'Adnān ibn Nașr al-'Aynzarbī (d. 1153 CE). Later in his life, he lived in Cairo, Egypt and became a personal physician to the Fatimid caliph az-Zăfir bi-Amr-Allāh. He wrote a treatise on the application of astronomy and astrology to medicine entitled Risāla fi-mā yahtāj aț-țabīb min 'ilm al-falak (What the physician needs to know of the science of the celestial sphere). In the treatise he explained how the different positions of the planets, and its relation to the different body parts in the doctrine of melothesy, can be used by physicians to prognosticate or diagnose illnesses. For example, he said, "Bleeding of the neck is unfavorable if the moon 
is in the sign of Taurus, that of the back when the moon is in the sign of Leo and generally, when the moon is in the sign of that limb which is to be cupped" (Ullmann, 1978). In his medical compendium, entitled al-Käfi fíl Ti ibb, and which was completed between 1116 $-1117 \mathrm{CE}$, he divided the book into three sections, and devoted the third section on astrology: 1. Medical generalities, public health and therapeutic care of the body, sleep and awake, physical exercises, pollution and environmental health and epidemiology.

2. Partial and general surgery from head to foot, and diseases and their causes, symptoms and treatments.

3. On how the physician could benefit from the knowledge of astrology. Al-'Aynzarbi explained how the different positions of the heavenly objects can guide physicians to predict, to prognosticate illnesses and to determine the right time and place to give treatment, medication and surgery. He also stressed that every physician should know the changes of time and seasons, the rising and setting of the constellations especially the twelve zodiacal signs, the directions of the winds, the condition of dwelling places, the availability of running waters and types of soil (Hamarneh, 1995).

Another physician-astrologer who also came from this eastern part of Islāmic land is the distinguished physician Abū Zakariyā Muḥammad ar-Rāzī (d. 925 CE). He devoted a small section in his Kitāb al-Hāwi (Liber Continens) on how the different positions and movement of the stars and planets can influence our health and sickness. He also wrote some treatises on astronomy and astrology, such as "The Form of the World (Astronomy of the Cosmos," "The Reason Why the Celestial Sphere Moves in its Rotation," "The Setting of the Sun and the Stars," and "The Extent to which it is Possible to Rectify Astrological Determinations in accordance with the Opinion of Natural Philosophers," and "Who Among Them that Denied that the Stars are Living" (Dodge, 1970).

In the Western part of Islāmic lands, in the Muslim Spain, astrology also took some root here. During the reign of 'Abd al-Rahmān I, there was alive a prominent Spanish astrologer known as 'Abd al-Wāḥid b. Isḥāq al-Ḍabbī (fl. ca. 184 AH/800 CE). And in twelfth century, there lived another famous Muslim astrologer, Abū'l-Ṣalt Umayya b. Abī'l-Salt (460 AH/1067 CE - 529 AH/1134 CE) (Samsó, 1994). Even the caliphs themselves took some interest in learning the art of astrology. It is reported that Caliph al-Mu'tamin of Zaragoza was said to have been skilled in astrology to the point of predicting the date of his own death in 1085 CE (Fletcher, 1992).

One of the well-known physician-astrologers to live in the Andalusian Spain was 'Arīb ibn-Sa'îd of Cordova (d. c. 980 CE). He was one of the prominent pediatricians in Islām, and wrote the first book in Islāmic medicine exclusively on the topic of pediatric, the caring of mother and child, in a treatise entitled Kitāb Khalq al-Janīn wa-Tadbìr al-Habālā wa-IMawlüdīn. Just as we have mentioned before that 'Arīb related each stage of the human life to a planet, and so in this book, he mentioned also how each stage of the human foetus is related to a planet:

"In the first month, when the foetus is still a formless drop, it stands under the sway of Saturn, whose nature is cold and dry. Because of this, the drop has no sense perception and no movement. In the second month it stands under the sway of Jupiter, whose nature is hot and wet. Now it begins to grow and to form into a lump of flesh. If it is a boy, its color is white and its shape round; if it is a girl, its color is red and its shape like that of a banana. In the third month Mars, who is hot and dry, holds sway. At this stage nerves and blood appear in the lump of flesh. The sun, which is likewise hot and dry, determines the fourth month 
when the fetus begins to move. When in the fifth month cold Venus holds sway, the brain, the bones and the skin form. Mercury, relatively hot and dry, influences development in the sixth month, when the tongue and the hearing develop. In the seventh month the fetus stands under the sway of the moon whose attributes are swift movements. By now the child is fully formed and thrusts outwards. If it is actually born in this month, it can live and grow, because it has experienced the influences of the seven planets in their entirety. However, if it remains in the womb, it again comes under the sway of Saturn in the eighth month, which is cold and dry. This quieting it, even makes it ill, so that if born now, it cannot live. But in the ninth month, Jupiter rules again, bringer of life and growth. If the child is born now, it will live and the same applies to the tenth month" (Ullmann, 1978).

Abū Marwān 'Abd al-Mālik ibn Abī-l-Alā' Zuhr (d. 1161/2 CE), one of the most distinguished physicians ever lived in al-Andalus, also believed that astrology can be very beneficial to medicine. He insisted that every surgical treatment, such as bloodletting and cupping, should be done after the proper time for its performance has been determined first through the positions of the stars and planets (Hamarneh, 1992).

Abū-I-Walìd Muhammad ibn Aḥmad ibn Rushd (d. 1198 CE), the distinguished physician-philosopher in al-Andalus, though he never really believed in astrology, did write some books in astronomy. Ibn Usaibi'ā reported that he has 4 books on astronomy, such as "Book on the Motion of the Sphere (Kitāb fi harakat al-falak) and "Summary of the Almagest" (Sarton, 1975).

\section{Conclusion}

Astrology, though it had many opponents among the Muslims scholars, did survive under the shade of medicine. Though we have mentioned here quite a number of physicians who believed and practiced astrology, they were also many of them who did not. The opposition from the religious factions was indeed quite strong, that many of the Muslim physicians, in order that their "foreign science" of medicine are not equally banned along astrology, felt the necessity to disassociate themselves from practicing it, and some of them even wrote treatises to announce publicly their disbelief toward astrology. But the fact that astrology is so thoroughly grounded in ancient medicine, that when the latter was transmitted to the Muslims, its presence was quite difficult to be discarded, and in addition to the Arabs continued pre-Islāmic interests in divination, astrology seemed to have some kind of revival, especially when the "new" form of astrology from the Greek and Persian were peppered with amazing and persuasive philosophical arguments. Without the modern equipment that we often have today, astrology in a sense seems to be better than not to have anything at all to guide a medieval Islāmic physician's way in the mysterious path of medicine. In other words, the science of medicine during this period of Islamic civilization seems to be quite conjectural as has been described by al-Ghazzālī, and even he, at first, seems willing to accept the validity of astrology inasmuch as he accepts medicine (Saliba, 1982).

\section{References}

Adams, F. (Tr.). (1978). Hippocratic Writings. In Maynard, Robert (Ed.). Great Books of the Western World, 10(9). Chicago: William Benton

Atiyeh, G. N. (1966). Al-Kindī: The Philosopher of the Arabs. Rawalpindi: Islāmic Reasearh Institute

Barton, T. (1994). Ancient Astrology. London: Routledge 
Browne, E. G. (1983). Arabian Medicine. Connecticut: Hyperion Press

Budge, E. A. W. (Tr.). (1976). The Syriac Book of Medicines. Amsterdam: Philo Press

Culianu, I. P. (1987). Astrology. Encyclopedia of Religion.

Dodge, Bayard (Ed.). (1970). The Fihrīst of al-Nadim: A Tenth Century Survey of

Muslim Culture. New York: Columbia University Press

Elgood, C. (1951). A Medical History of Persia. Cambridge: Cambridge University Press

Fahd, T. (1983). Hurüf ('Illm al-). Encyclopedia of Islām.

Fahd, T. (1983). Nujūm (Aḥkām al-). Encyclopedia of Islām.

Fletcher, R. (1992). Moorish Spain. London: Weidenfeld \& Nicolson

Gamal, A. S. (Ed.) \& Dols, Michael W. (Tr.). (1984). Medieval Islāmic Medicine: Ibn Riḍwān's

Treatise "On the Prevention of Bodily Ills in Egypt." Berkeley: University of California Press

Haddad, F. I., Pingree, D., \& Kennedy, E. S. (1984). Al-Bīrūnī's Treatise on Astrological Lots.

Zeitschrift für Geschichte der Arabisch-Islamischen Wissenchaften, 1, 9-54.

Hamarneh, S. K. (1994). The Banū H.akam: Pioneer Arab Medical Family (Flourished, C.E. 660-

840). Studies in History of Medicine and Science, 8(2), 142.

Hamarneh, S. K. (1995). Medicine and Pharmacy in al-Andalus (Tenth- Twelveth Centuries).

Hamdard Medicus, 38(4), 26.

Kunitzsch, P., \& Hartner, W. (1983). Mințaḳat al-Burūj. Encyclopedia of Islām.

Kunitzsch, P. (1983). Al-Nujūm. Encyclopedia of Islām.

Modi, J. J. (1910). A Mahomedan View of Comets. Revue du Monde Musulman, 10, 42-3.

Namus, M. S. (1979). Al-Bīrūnī, the Greatest Astrologer of the Times. In Said, Hakim Mohamad

(Ed.). Al-Bïrūnī Commemorative Volume (p. 550). Karachi: Hamdard National Foundation

Nasim, K. B. (1979). Al-Bīrūnī, as an Astrologer. In Said, Hakim Mohamad (Ed.). Al-Bīrūnī

Commemorative Volume (p.580). Karachi: Hamdard National Foundation

Rosenthal, Franz (Tr.). (1967). Ibn Khaldun's Muqaddimah: An Introduction to History.

London: Routledge \& Kegan Paul

Sabra, A. I. (1992). Abū al-Hasan Thabit bin Qurrah as-Sabī' al-Harrani.

Siddiqi, M. Z. (Ed.). (1928). 'Alī b. Rabban aț-Ṭabarī: Firdausu'l Hịmat. Berlin: Buch-U, Kunstdruckerei

Ullmann, M. (1951). Islāmic Medicine. Cambridge: Cambridge

University Press

Hayes, J. R. (Ed.). The Genius of Arab Civilization: Source of Renaissance (pp. 198-9). New York: New York University Press

Saliba, G. (1982).Astrology/Astronomy. Dictionary of the Middle Ages

Samsó, J. (1994). The Exact Sciences in al-Andalus. In Jareyusi, Salma Khadra (Ed.).

The Legacy of Muslim Spain (p. 956). Leiden: E.J.Brill

Sarton, G. (1975). Introduction to the History of Science. New York: Robert E.

Krieger Publishing Company

Schaht, J. \& Meyerhoff, M. (1937). The Medico-Philosophical Controversy between Ibn

Butlan of Baghdad and Ibn Ridwan of Cairo. Cairo: The Egyptian University 